\title{
A ÉTICA DO DISCURSO NA CONSTRUÇÃO DE UM AGIR ÉTICO NA MANIPULAÇÃO DA ESPÉCIE
}

\section{ARTIGO ORIGINAL}

SANTOS, Miguel da Silva ${ }^{1}$

FERRIZ, José Luis Sepúlveda ${ }^{2}$

SANTOS, Miguel da Silva. FERRIZ, José Luis Sepúlveda. A ética do discurso na construção de um agir ético na manipulação da espécie. Revista Científica Multidisciplinar Núcleo do Conhecimento. Ano 05, Ed. 01, Vol. 07, pp. 151-173. Janeiro de 2020. ISSN: 2448-0959, Link de acesso: https://www.nucleodoconhecimento.com.br/filosofia/etica-do-discurso

\section{RESUMO}

Este artigo apresenta os argumentos que Habermas utiliza para estabelecer mecanismos éticos com vistas às questões da manipulação genética, mais especificamente o problema da eugenia. A razão comunicativa na filosofia da linguagem é a base para o estudo bem como o discurso e consenso mediados pela argumentação de proposições morais válidas entre sujeitos capazes de agir e falar. A auto-compreensão da existência e autocompreensão ética se situam como elementos de intersubjetividade, liberdade e dignidade humana da pessoa, que estão presentes mesmo desde a sua concepção. Os conceitos kierkegaardianos da existência aliamse à perspectiva pós-metafísica da filosofa analítica, tendo como centro a capacidade de tornar-se indivíduo diante de uma autocompreensão ética da espécie. Apresenta a

1 Pós-graduação em Gestão Ambiental, Graduação em Engenharia Química, Graduação em Filosofia, Aluno Especial do Curso de Mestrado em Filosofia da UFBA. 2 Doutor em Filosofia Ética e Política pela Universidade Complutense de MadriEspanha. Mestre em Estudos Avançados em Filosofia pela Universidade Complutense de Madri-Espanha. 
questão da dignidade humana do embrião, tendo como suporte o começo da vida humana e sua inclusão no mundo da vida. Além disso, apresenta conceitos e noções sobre biologia genética com o objetivo de esclarecer a terminologia técnica apresentada durante o desenvolvimento do trabalho. A metodologia a ser utilizada é a estrutural, a qual é apresentada, em geral, nas obras de Habermas. A pesquisa bibliográfica de referenciais teóricos será utilizada como material complementar.

Palavras-chave: Habermas, Razão Comunicativa, Eugenia, Ética, Autonomia.

\section{INTRODUÇÃO}

A Filosofia como disciplina do pensamento está sempre disposta a penetrar nos diversos embates cujos conceitos do ultra óbvio da ciência se posicionam numa autonomia limitada por fatores naturais, culturais, sociais, entre outros, e, por sua vez, exigem respostas, às vezes imediatas, para as questões que atingem o ser humano nas suas diversas antropologias. A vida humana está pautada em princípios e valores morais que ordenam a sua conduta, em sintonia com os seus semelhantes. Para Rousseau (2000), a natureza humana é boa e a sociedade é quem a corrompe. Essa bondade natural seria, então, aos poucos, destruída e corrompida pela civilização. Portanto, a sociedade poderia ser auto ajustável moral e politicamente. Por outro lado, Hobbes (2009) traz, em seus escritos, que no estado de natureza a vida humana está em uma guerra de todos contra todos, pois todos os indivíduos teriam permissão para possuir qualquer coisa, por meio de suas paixões e desejos.

Nesse caso, a sociedade necessitaria de uma autoridade à qual todos deveriam submeter a sua liberdade natural. Talvez nem tanto para Hobbes, nem tanto para Rousseau, mas é preciso estabelecer uma matriz de comportamento que dê condição de sustentação e permanência do indivíduo e de sua coletividade no planeta. É nesse contexto que entra a Bioética, nascida para dar as provisões necessárias para os procedimentos éticos que envolvem as determinações sobre a biota terrestre, com um grande viés nas manifestações do homem sobre a natureza, o que inclui o próprio homem. O manuseio do homo somaticus pelo homo faber tem que entrar nessa discussão sob pena de se estabelecer um caos ético. Aqui se insere a manipulação 
genética da espécie humana, que, na sua parte mais delicada, contempla a questão do "bem-nascido", ou seja, a eugenia.

A eugenia, na sua forma altamente relativizada, ou seja, liberal, torna-se, aqui, uma porta aberta para a coisificação da alma racional, ignorando a sua liberdade de decisão como agente no processo de escolha de uma possibilidade de "vida melhorada". O tema tem uma relevância muito grande porque envolve o futuro de uma humanidade que não terá a oportunidade de reverter decisões tomadas por mediadores de uma discussão puramente unilateral. A Filosofia, com sua inserção nessa discussão, tem a função importante de gerar fundamentos para a elaboração de normas morais e legais estabelecedoras de limites de condutas. A proposta deste artigo é tentar entender como a Filosofia se posiciona, em relação ao agir ético, nas condutas de intervenções genéticas humanas, uma vez que elas vêm sendo abordadas praticamente no campo da Medicina, do Direito e da Teologia.

A questão aqui suscitada tem a ver com a liberdade do indivíduo, que é ontológica, e, portanto, intrínseca ao ser humano, o que o faz tomar suas decisões, ao nosso ver, a partir de vontades epistemológicas heterônomas. $O$ estudo é baseado na obra $O$ Futuro da natureza humana, de Jürgen Habermas (2004) , um dos grandes pensadores contemporâneos, que traz uma abordagem um tanto quanto inovadora para o tema ético em questão, em um cenário de predomínio da filosofia pósmetafísica, cabendo, assim, acrescentar à problemática a seguinte indagação: como a pós-metafísica habermasiana pode colaborar no estudo de um agir ético na manipulação do genoma humano? O método estrutural empregado neste estudo está pacificamente aprovado como o método que mais se adequa aos textos filosóficos. A arquitetura empregada se baseia na aglutinação de diversas áreas de pensamento, de ideias, de conhecimentos, em um todo, coordenados por este todo.

Pela análise das estruturas e de suas disposições superpostas e pelo desencadeamento de seus processos intelectuais, podemos fazer uma interpretação mais próxima do sentido dado pelo autor ao texto filosófico, compreendendo a sua totalidade. O artigo está estruturado em três partes principais que mostrarão os fundamentos necessários para a compreensão do desenvolvimento das ideias do 
autor, extraindo destas a nossa análise e reflexão. Como se trata de um tema que envolve saberes do campo da biologia genética, na primeira parte será feita uma abordagem conceitual sobre este assunto, em especial sobre a manipulação genética e a eugenia, com a finalidade de introduzir os conhecimentos técnicos que serão alinhados com os aspectos filosóficos mais adiante. Na segunda parte serão desenvolvidos os temas que envolvem a pós-metafísica, principalmente aquela na qual Habermas se apoia para desenvolver suas teses do agir comunicativo e do si mesmo, tendo esta última uma imersão na ética kierkegaardiana.

Nesse capítulo será mostrado o percurso do pensamento filosófico tradicional - a filosofia da consciência - que, por meio da chamada virada linguístico-pragmática, a razão estará presente nos jogos de linguagem que incluem sujeito, ação e fala numa relação intersubjetiva. Habermas traz, também, Kierkegaard, outro existencialista, para esse contexto (HABERMAS, 2004). Este é o pensador que sonda o indivíduo no seu estádio ético, envolvendo-o em uma necessidade de autoconhecimento da sua intersubjetividade e do seu poder ser si mesmo na existência da vida. Nesse capítulo será exposta a formulação de uma ética baseada no discurso, cujas subjetividades dos protagonistas serão submetidas aos conceitos de moralidade e eticidade.

Na terceira parte, recuperando todos os assuntos dos capítulos anteriores e perfilando com as ideias de Habermas na obra base deste estudo - O Futuro da natureza humana -, será mostrado o caminho adotado para se entender e estabelecer uma postura ética para o tema proposto neste trabalho e o trabalho buscará atender à problemática que a ele deu origem. O estudo passa por uma compreensão dos modelos eugênicos, das indefinições sobre limites entre as intervenções terapêuticas, pelo aperfeiçoamento fenotípico[3] e pelas responsabilidades éticas dos personagens desta manipulação genética quando há a inclusão de uma segunda pessoa, significada pelo "tu", nas questões decisórias ontológicas. Trata, também, esse capítulo, da dignidade humana como resultado da autonomia e autenticidade do indivíduo, dignidade essa inserida na normatização jurídica - assunto implícito na obra do autor. Confronta-se a isso a questão da "fabricação" eugênica do "eu" na instrumentalização da vida humana. 


\section{ALTERAÇÕES GENÉTICAS DA ESPÉCIE HUMANA - CONCEITOS FUNDAMENTAIS}

A genética é um dos ramos que mais tem contribuído para o avanço da ciência biológica. Como ciência, ela se insere num cenário mais amplo e profundo que busca explicações para a origem das espécies, prolongamento da vida humana e compreensão de fenômenos que antes só se presumia por completo por meio do senso comum. Com o advento de ferramentas poderosas, como, por exemplo, com o aperfeiçoamento dos microscópios celulares e eletrônicos, com o avanço da biologia molecular e da bioquímica bem como com o aumento de investigações científicas a respeito do genoma humano nos dois últimos séculos, alguns paradigmas começaram a ser destelhados, como, por exemplo, a determinação do sexo na fase embrionária, conduzindo, dessa forma, a Biologia e a Medicina para a pós-modernidade e, por que não, para um mundo plural?

Do ponto de vista técnico, as questões envolvendo o uso de unidades elementares biológicas podem ser vistas, principalmente, em temas como reprodução humana, clonagem, elaboração de organismos geneticamente modificados (OGM), transgenias, terapias genéticas, aperfeiçoamento genético e pesquisas com embriões e células-tronco. A manipulação genética, por sua vez, insere-se em todos esses temas (ou áreas), sendo necessária, portanto, a realização do manuseio de genes para a condução deles. A leitura atual se concentra na chamada engenharia genética que trata, principalmente, das modificações genéticas provocadas ou induzidas. A origem das discussões está nas alterações provocadas no DNA, ou de partes dele, para se conseguir um desvio do caminho natural das espécies a partir de suas origens formadoras mais remotas.

Os segmentos de DNA que contêm a informações genéticas são denominados genes. Todas as informações genéticas de determinado indivíduo como a cor dos cabelos, a cor dos olhos, a estrutura física e outras características hereditárias estão presentes no DNA da pessoa. A manipulação dos genes determina o modelo de espécie que queremos ter e atende certas necessidades ou vontades do indivíduo ou da 
coletividade. E tudo começa, praticamente, com a identificação de determinado gene de interesse na estrutura do DNA, sua remoção, alteração por corte (utilizando as chamadas enzimas restritivas) e depois a inserção em outra estrutura (por meio do chamado DNA-ligase), conforme mostrado na Figura 1. Fica, dessa forma, estabelecida a era da manipulação de mensagens genéticas contidas em fragmentos de sequências que compõem o código hereditário e os nucleotídeos (cada unidade formadora do DNA).

É válido reiterar que foi a partir deste momento que, por exemplo, a esfera da Engenharia Genética passou a cortar ou modificar as moléculas de DNA, utilizando, para a realização desse processo, enzimas específicas. É de igual relevância mencionar que a inserção de fragmentos de DNA com informações de interesse em outro cromossomo visa produzir os chamados organismos novos ou melhorados. Isso tem aplicação no campo da Medicina, da Farmacologia e da Produção de Alimentos. Outra área de aplicação que começou a aflorar no século $X X$ e vem se intensificando no presente século diz respeito à manipulação de genes para aperfeiçoamento da espécie humana e a prevenção e cura de determinadas patologias. A estes processos dá-se o nome de eugenia.

Em 1883 o inglês Francis Galton (GALTON apud GOLDIM, 1998) utilizou este termo, que tem origem na palavra grega Eugénios - "bem-nascido", para definir um processo que visava selecionar espécies humanas entre mais capazes e menos capazes, conceituando eugenia como o estudo dos agentes sob o controle social que podem melhorar ou empobrecer as qualidades raciais das futuras gerações, seja física ou mentalmente. Com o advento da manipulação genética, a intervenção nos genes com o objetivo de aperfeiçoamento humano passou a ser definida como eugenia positiva e o chamado uso terapêutico das alterações genéticas, utilizadas para cura e antecipação de diagnóstico de doenças tomou o nome de eugenia negativa. 
Figura 1 - Inserção de informação genética

\section{Before Insertion}

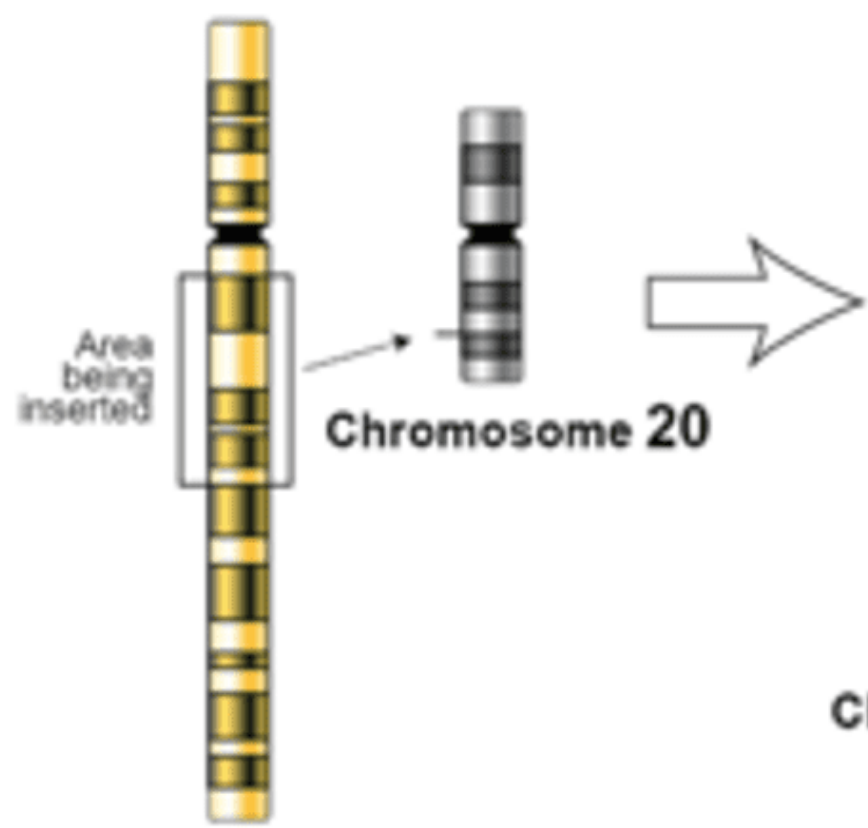

After Insertion

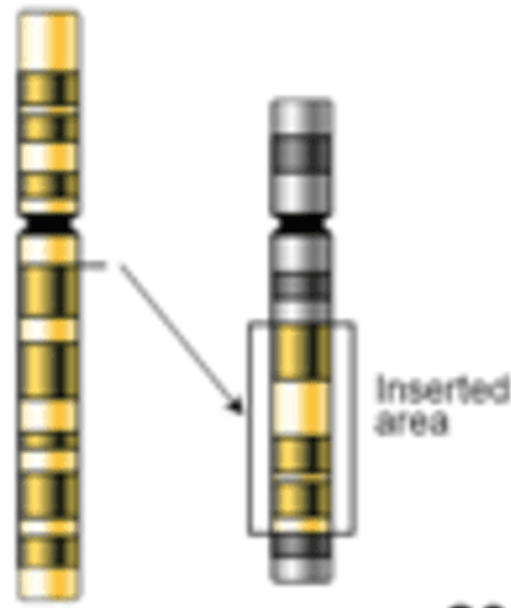

Chromosome 20 Chromosome 4

\section{Chromosome 4}

Fonte: Ver nota[4]

A hereditariedade humana é o pano de fundo para balizar as discussões éticas, tanto no seu modo de conceber como na sua forma de dar prosseguimento ao seu produto gerado. É nela que situa o conflito ético, uma vez que a manipulação genética se dá em um embrião que é coletado durante o seu desenvolvimento no processo de reprodução humana para avaliação do seu status patológico ou fenotípico por meio do chamado Diagnóstico Genético de Pré-Implantação (DGPI). O progresso da ciência genética leva a reflexões acerca de determinadas questões éticas, como o descontrole da humanidade no uso e obtenção de embriões humanos. É notório que as técnicas de reprodução humana assistida possibilitam casais com dificuldade de concepção a terem filhos, mas, por outro lado, eles se defrontam, na maioria das vezes, com a decisão sobre o destino dos embriões excedentes não utilizados no procedimento médico. 
Um dos pensadores que aborda sobre a relevância ética destes temas tão contemporâneos é Jürgen Habermas. Ele será o nosso autor basilar ao longo deste trabalho. Na obra O Futuro da Natureza Humana, Habermas lança a seguinte pergunta-desafio: "pode a filosofia se permitir a mesma moderação[5] também em questões relativas à ética da espécie?" (HABERMAS, 2004, p. 1). O seu envolvimento parte daí e ele percebe que tratar o dilema da manipulação genética apenas na sua cientificidade significa tratar o sujeito isoladamente e o estudo tem que ser realizado considerando o sujeito em interação com o mundo e o sujeito com sujeito. É nesse momento que entra, então, a pós-metafísica em seus trajes de discurso, mas tendo, na essência, a linguagem dentro de ações comunicativas. Ele vai conduzir a suficiente objetividade das ciências biológicas para a necessária intersubjetividade das ações e da fala, interpretando o ser como a pessoa formada na sua origem para qualquer que seja o entendimento: normativo, sociológico ou teológico.

\section{O PENSAMENTO PÓS-METAFÍSICO COMO INSTRUMENTO PARA A BIOÉTICA}

Pode-se dizer que o universo fundamental no qual se desenvolve o pensamento ético de Habermas é o da Filosofia da Linguagem. É nesse contexto que ele situa a ética no campo do discurso e da comunicação, não perdendo de vista a racionalidade, sendo essa a razão pela qual ele discorre sobre uma racionalidade comunicativa. E é ancorado no protótipo da linguagem que Habermas recusa o retorno aos pressupostos filosófico-históricos, como a metafísica. Ou seja, em Habermas, o que norteia a ética é o paradigma da comunicação. Na sua estrutura argumentativa ele também faz uma aplicação da ética de ser si mesmo de Kierkegaard e da teoria kantiana da justiça, com a ressalva que esta faz em sua abstração e para o todo universal. Defende ele a ideia de que "o pensamento pós-metafísico deve impor a si próprio uma moderação quando se trata de tomar posições definitivas em relação a questões substanciais sobre a vida boa ou não fracassada" (HABERMAS, 2004, p. 1).

Contudo, quando entra em jogo a manipulação de genomas, ele também questiona se "pode a filosofia se permitir a mesma moderação também em questões relativas à 
ética da espécie?" (idem). Baseado nesses arrazoados, Jürgen Habermas vai incluir na formulação de seu pensamento pós-metafísico uma ética baseada no discurso, na intersubjetividade e na liberdade. A pós-metafísica foi uma alternativa que, a partir do século XIX, buscou conceber a razão a partir da inclusão do elemento intersubjetivo na construção de valores, baseada, principalmente, no agir comunicativo. Apesar de renunciar aos conceitos ontológicos sobre a totalidade do ente, o pensamento pósmetafísico recupera da ontologia o ser enquanto sujeito da realidade objetiva e nesta realidade ele se constrói com intersubjetividades.

Na nova construção filosófica, o sujeito se situa em outro cenário, passando de uma consciência do sujeito para o sujeito da consciência. Agir pela linguagem e o comprometimento em atos comunicativos na construção de uma racionalidade são os fundamentos para se tentar resolver uma das questões emblemáticas da filosofia que é a individualidade. Nesse contexto, afirma Habermas:

A passagem da filosofia da consciência para a filosofia da linguagem traz vantagens objetivas, além de metódicas. Ela nos tira do círculo aporético onde o pensamento metafísico se choca com o anti-metafísico, isto é, onde o idealismo é contraposto ao materialismo, oferecendo ainda a possibilidade de podermos atacar um problema que é insolúvel em termos metafísicos: o da individualidade (HABERMAS, 1990, p. 15)

Substitui-se a filosofia do eu, da consciência do sujeito (filosofia da consciência), por uma outra cujo modelo é baseado na linguagem. O sujeito, agora, passa a ser o sujeito articulador de frases, de sinais, de fala, capaz de compreender por meio da linguagem e dar significado à comunicação do seu pensamento, de suas ideias[6].

Os sujeitos capazes de fala e ação, que ante o pano de fundo de um mundo comum da vida, entendem-se mutuamente sobre algo no mundo, podem ter frente ao meio de sua linguagem uma atitude tanto dependente como autônoma: eles podem utilizar os sistemas de regras gramaticais, que tornam possível sua prática, em proveito próprio (HABERMAS, 1990, p.52). 
Nesse aspecto, introduz, com certa clareza , o agir comunicativo habermasiano, pois, a intersubjetividade, é necessária para o movimento de um todo moldado pela ação de cada para cada um, o que leva a desdobramentos, ou seja, à readequação, no agir ético do imperativo categórico kantiano que assim se expressa: "age só, segundo uma máxima tal, que possas querer ao mesmo tempo que se torne lei universal" (KANT, 1993, p. 70). Tomando como ponto de partida o sujeito, agora localizado, não como o ser da filosofia da consciência ou como o ser que paira no quantum ideal da metafísica, nem como o ente que interage no mundo do nada heideggeriana. Tratase de um ser que se faz sujeito com o sujeito no mundo. É a partir disso que Habermas elabora a sua Teoria do Agir Comunicativa (TAC), fundamentada em discussões acerca da ação, da linguagem e da semântica, com o objetivo de dar um encaminhamento mais pragmático às questões filosóficas e sociais que até agora eram eivadas de concepções praticamente supra teóricas.

A preocupação dele não é criar um conceito revolucionário de filosofia e racionalidade, mas sim uma teoria amparada no agir comunicativo, dirigida às estruturas do mundo da vida. O "mundo da vida", conceito originado na fenomenologia, agora se amplia para abranger não somente o horizonte da consciência, mas também o contexto da comunicação linguística, a práxis comunicativa do dia a dia, o que se realiza por meio da fala. Ele é constituído de três componentes estruturais: cultura, sociedade e pessoa. Ao analisarmos, posteriormente, as questões referentes à manipulação genética, a abordagem desses conceitos terá, ali, um cenário de caso concreto de materialização das transformações históricas da humanidade - aplicação do conceito marxista - em que "a humanidade se dispõe praticamente a fazer sua história, que de resto, ela sempre faz, com vontade e consciência" (HABERMAS, Theorie und Praxis, in PINZANI, 2009, p. 48). Em Habermas (2004), as discussões foram conduzidas com base nos seguintes movimentos históricos da prima philosophia:

1. O surgimento do método experimental das ciências da natureza suspende o juízo acerca do pensamento totalizador com vistas no uno e no todo.

2. O surgimento da hermenêutica, enquanto ciência, no embate ao idealismo de transcendentalização. 
3. A mudança da filosofia da consciência para a filosofia da linguagem, direcionando a auto compreensão subjetivista para o centro da razão.

4. O agir comunicativo desloca a antiga tradição que dava primazia à teoria frente a práxis.

As discussões que tratam das alterações genéticas induzidas, ou provocadas, na espécie humana, passam por esse conjunto de abordagens, mas tem um forte apelo nos dois últimos, quando será tematizado um discurso ético de construção intersubjetiva a partir da linguagem no agir comunicativo. Na formatação pósmetafísica que Habermas apresenta na sua obra O Futuro da Natureza Humana, ele traz à luz uma visão também pós-metafísica do conceito de eticidade sob a ótica de um filósofo existencialista contemporâneo, Sören Kierkegaard, explorando o conceito do si mesmo (HABERMAS, 2004). Poder-ser-si-mesmo só cabe na compreensão quando se capta a realidade do indivíduo dentro da sua subjetividade e é essa subjetividade que Kierkegaard (2013) traz como elemento principal do sujeito que existe no mundo dos fatos para alcançar sua liberdade.

É o mundo das possibilidades que se movimenta por meio de três estádios da vida do sujeito: o estético, o ético e o religioso, que, por ser mundo de possibilidades, significa, também de escolhas. Portanto, a subjetividade em Kierkegaard significa escolher a si mesmo para tornar-se um indivíduo perfeitamente livre, isto é tornar-se a si mesmo. O si próprio se estabelece nessa busca da interioridade do ser. É o devir da existência que nos faz estar sempre em transformação a partir de nossas escolhas que compõem a própria existência, daí que existência é necessidade e possibilidade e isso é raiz da angústia natural do indivíduo que deve ser trabalhada pelo autoconhecimento e reconhecimento de sua singularidade. O indivíduo pode ser si mesmo quando é capaz de tornar-se para essa interioridade e quando faz parte de sua própria realidade por meio de escolhas.

Somente cabe ao indivíduo o acesso a essa realidade, que é subjetiva e que é a fonte de suas verdades, isto é, esta realidade subjetiva é a verdade. É em meio a essas possibilidades que a existência é livre, ela pode ser. Quando o indivíduo se harmoniza com o poder ser, isto é, com possibilidades, ele consegue escolher o cenário de sua 
vida que the conduz à liberdade. Esse cenário que Kierkegaard chama de estádios[7] - estético, ético e religioso (NUNES, 1967) -representa o todo do, e no, indivíduo sem que perca sua subjetividade e se firme na sua existência. Aqui ele escolhe seu estádio com base em sua autoconscientização e autocompreensão[8], sabendo que a passagem de um para outro é dado por salto qualitativo. O ético é caracterizado pelas relações intersubjetivas, sem se despojar da subjetividade. É aqui que o sujeito tem a percepção horizontal do seu pertencimento no mundo, pois essa horizontalidade é que o faz se aproximar e se colocar em alteridade com o semelhante.

O si mesmo é essa liberdade que vem pela individualidade para dar sentido à existência; e o ser si mesmo é algo como um poder adquirido pelo indivíduo desde a sua genesis, que lhe dá livre acesso à sua autocompreensão e à intersubjetividade e que só se coaduna com o si mesmo do outro quando essa liberdade não é maculada. O sujeito torna-se, então, autor da sua própria existência e capaz de construir um discurso ético sob consenso, baseado em argumentos morais por ele validado. Quando trata das questões morais e éticas no agir comunicativo sobre a manipulação genética em estudo, o filósofo propõe e elabora a sistematização de uma ética comunicativa, fundamentada em sua obra Consciência moral e agir comunicativa (1989). Segundo Habermas, há uma ligação radical, praticamente amalgamada, interpenetrada, entre realidade e linguagem no mundo da vida.

Essa ligação se associa, também, à ação e às manifestações nas formas de argumentação das ideias geradas pelo raciocínio: argumentações que objetivam validar um discurso para a construção de uma ética aplicada à conduta dos sujeitos no mundo real. $\mathrm{O}$ compêndio ético de Habermas baseia-se no projeto dessa ética comunicativa, iniciada nos anos 70, orientado por normas, portanto, deontológicas, universais, criadas por meio de procedimentos (discursos) cujos seres humanos podem participar, dentro de sua classe de interesse. Nessa ética do discurso, as questões morais voltam-se às questões do mundo da vida e se relacionam à vida boa, o que significa que, em que pese a sua universalidade, somente os participantes desse mundo, concreto, real, podem avalizar se uma norma é aceitável ou não. Nessa esteira, ele parte de uma distinção propositiva entre o ser e o dever ser, atribuindo, ao 
ato assertórico (ser), uma pretensão de verdade e, ao ato deontológico (dever ser), uma pretensão de validade.

O dever ser faz parte do próprio processo argumentativo nas proposições éticas e, por outro lado, a argumentação orienta o ser e o dever ser, uma vez que proposições assertóricas podem se revelar verdadeiras ou falsas e o argumento deôntico pode ser válido ou não. Os conceitos desenvolvidos na Teoria do Agir Comunicativo se alinham com esta distinção propositiva a partir das duas formas de agir - o agir estratégico e o agir comunicativo. No agir estratégico, o indivíduo trabalha no sentido de fazer com que outra pessoa atue da forma que ele considera adequada (proposição assertórica com pretensão de verdade), e, no agir comunicativo, o sujeito busca convencer o outro de que deveria agir da forma adequada, induzindo-o ao seu posicionamento (proposição deôntica com pretensão de validade). No caso da norma, o que confere validade a ela é a verificação de sua eficácia e legitimidade, à medida que ela pode ser eficaz e ilegítima.

Segundo Habermas, "temos que distinguir o fato social do reconhecimento intersubjetivo e o fato de uma norma ser digna de reconhecimento" (HABERMAS, 1989, p. 82), assim, o reconhecimento intersubjetivo se refere à eficácia e a dignidade de reconhecimento à legitimidade. A aplicação desses dois componentes da moral prática nos dá a possibilidade de analisar, do ponto vista ético, as questões eugênicas tanto do passado (arianismo hitleriano) quanto as atuais movimentações genéticas nesse sentido. As normas consideradas válidas têm que ter o reconhecimento, serem aceitas (acordadas) por todos os "concernidos", porque vão tratar, unicamente, dos seus interesses comuns. De acordo com Habermas toda norma válida deve atender a seguinte condição:

que as consequências e feitos colaterais, que (previsivelmente) resultarem para a satisfação dos interesses de cada um dos indivíduos do fato de ser ela universalmente seguida, possam ser aceitos por todos os concernidos (e preferidos a todas as consequências das possibilidades alternativas e conhecidas de regragem) (HABERMAS, 1989, p. 86). 
Para tornar realidade a ética do discurso é preciso que a argumentação sobre a validade das proposições deônticas (normas) se realize no exercício efetivo do discurso, isto é, no agir comunicativo com vistas ao consenso e ao entendimento, no qual "toda norma válida encontraria o assentimento de todos os concernidos, se eles pudessem participar de um Discurso prático" (HABERMAS, 1989, p.148).

\section{A EUGENIA E A ÉTICA DA ESPÉCIE}

Ser (assertórico) e dever ser fazem parte da estrutura ontológica e deontológica, portanto, filosófica, que compõem o estudo ético-universal da sociedade desde a antiguidade clássica. Estudo este que tem, na universalidade, seu principal eixo de apoio. Entretanto, quando se trata da delimitação e confinamento do ser humano nos seus espaços de poder-ser-si-mesmo, por meio da manipulação do homo somaticus pelo homo faber, talvez tenhamos que repensar qual o modelo de ética que deveremos adotar para fazer frente aos novos padrões morais de consumo desse século. Repensar a Filosofia como ciência primeira tem estado no escopo dos pensadores modernos, principalmente no campo da moral e da ética, como Hans Jonas, Emanuel Lévinas, Alasdair MacIntyre, entre outros, uma vez que o ser humano, como sujeito da ontologia, da antropologia e da epistemologia, além de gerador dos fatos sociais, modifica-se nas dimensões temporais e espaciais.

A pergunta lançada por Habermas "O que devo fazer com o tempo da minha vida?" (HABERMAS, 2004, p. 3), antes de uma interpretação moldada na individualização e na subjetivação humana, apresenta-se como uma necessidade para a tentativa de rompimentos paradigmáticos éticos tradicionais sem que haja perda de princípios que nomeiam a humanidade como substância do ser humano, pois se trata, também, de uma preocupação com a manutenção de valores tornados obsoletos neste momento em transição. Com base na teoria da justiça de John Rawls (2000), Habermas traz a concepção de uma sociedade justa como aquela que "deixa ao critério de todas as pessoas aquilo que elas querem iniciar com o tempo de suas vidas" (HABERMAS, 2004 , p. 5) e "ela garante a todos a mesma liberdade para desenvolver uma autocompreensão ética, a fim de formar uma concepção pessoal da "boa vida" segundo capacidades e critérios próprios" (idem). 
Assim, o autor indica que deve haver a transição de uma ética universalizada para uma autonomia ética do indivíduo que pode construir seu próprio modelo de vida. Nesse sentido, a pergunta "O que devo fazer com o tempo da minha vida" pode ser respondida pelo sujeito que a faz, ou seja, cada um decide como conduzir sua vida, cada ser humano é responsável pela utilização do seu poder de intervir na vida, um desafio que se afigura do atual modelo de liberdade, já com um olhar para as condutas autodeterminadas e heterodeterminadas da manipulação genética. A autocompreensão ética vai servir de moldura para uma autocompreensão da existência que é peça chave para que a moral, a justiça e a política deem respostas ao agir correto. Sem ela nada se efetiva de verdade porque o sujeito tem que ser pessoa e ser capaz de poder ser si mesmo e essa percepção intuitiva da existência vai dar os recortes que caracterizam uma vida boa ou fracassada.

Com isso chegamos as bases em que Kierkegaard traça seu modelo de conduta para o indivíduo, pois existência e "condição de vida" fazem parte do seu pensamento pósmetafísico. O poder ser si mesmo de Kierkegaard se realiza na existência humana que navega em uma dialética do "si para consigo", sem haver negação de um para o outro. O poder ser si mesmo envolve escolha e, dessa forma, Kierkegaard trata da autonomia da relação razão/vontade do indivíduo, o qual deve construir, a partir de sua própria consciência, o controle de sua vida. $\mathrm{O}$ indivíduo que teve sua vida instrumentada pela manipulação genética torna-se, então, refém da razão/vontade de terceiros e essa consciência da historicidade, em vez de ser um atributo da sua existência, passa a ser, também, produto de manipulação social que começou em sua vida pré-pessoal.

A consciência ética, o querer tornar-se, assim como a moral subjetiva, advém do reconhecimento e relacionamento com "Alguém" que está acima de qualquer limitação, de um poder que não está disponível em nós. Esse poder transcendental, localizado no estádio religioso kierkegardiano, pode ser projetado para um entendimento transubjetivado no reconhecimento horizontal de um outro, o que nos coloca como parceiros no processo do agir comunicativo, como sujeitos capazes para a linguagem e ação. Estabelece-se, assim, um tangenciamento entre a pós-metafísica 
da linguagem e o poder ser si mesmo existencial que tem elo com a transcendentalidade. Constrói-se aqui, então, uma transposição da pós-metafísica kierkegaardiana para uma pós-metafísica da linguagem, mas sem perder a conexão que há entre elas.

Linguagem e ação são meios de comunicação entre sujeitos morais, mas o logos da língua está vinculado a algo que está além do sujeito (transubjetivo), que é quem nos oferece as condições para a autocompreensão ética. A compreensão pela comunicação não vem pelo simples ato e simples linguagem. É a partir do logos (da razão) que construímos esse intercâmbio de mensagens, do um com um outro. Essa conjunção de pensamentos pós-metafísicos leva ao rompimento da moderação (comedimento) da pós-metafísica quando se trata da ética da espécie. A Filosofia se apropria da discussão do tema uma vez que o sujeito, agora já habilitado pela linguagem e pela ação, passa a ter uma autocompreensão ética. Ter um corpo natural ou construir um corpo passa, então, a entrar num debate em que a existência objetiva tem que ser analisada conjuntamente com a subjetividade da existência.

De certa forma, a relação entre "ser um corpo" e "ter um corpo" pode ter conotações diferentes dependendo do sujeito que a vê e da percepção que ele tem da espécie humana. Uma vez que a autocompreensão existencial e ética não tenha relevância na moral universalizada o indivíduo fica refém, desde a sua pré-pessoalidade, a objetivos que satisfazem a modernidade cultural, tutelados apenas pelo simples dever ser legal. Isso leva à liberalidade da intervenção, por exemplo, no genoma humano por meio das práticas da eugenia. A despeito de tais intervenções genéticas a história pessoal do indivíduo, portanto a própria biografia, abstém-se do processo contingente e da imprevisibilidade, ambos intrínsecos à natureza do "ser" humano, interferindo precocemente na sua autocompreensão do poder ser si mesmo. É de relevante significado o que Habermas afirma:

Com a decisão irreversível que uma pessoa toma em relação à constituição "natural" de outra, surge uma relação interpessoal desconhecida até o presente momento. Esse novo tipo de relação fere nossa sensibilidade moral, pois forma um corpo estranho nas relações 
de reconhecimento legalmente institucionalizadas nas sociedades modernas (HABERMAS, 2004, p. 20).

O autor vai mais além sobre a questão da autoconsciência como elemento primordial da subjetividade quando faz entender que tanto na manipulação genética como no manuseio de genes em adultos para clonagem a questão se depara com essa compreensão ética interior da humanidade como um todo. Entretanto, ainda que isso seja necessário para parametrizar entendimentos e concepções, o que se vê é a especulação de normas morais e jurídicas para dar legitimação às orientações axiológicas, o que significa dizer que, atualmente, o ser humano está condicionado a viver praticamente sob essas normas. A moral e o direito natural do indivíduo e da coletividade, não conseguem ter aplicação e nem sobreviveriam, enquanto nossa mente permanecer voltada para um estado hobbesiano.

Uma vez que a condição humana (como vimos no capítulo anterior) é a da guerra de uns contra os outros, cada qual governado por sua própria razão, e não havendo algo de que o homem possa lançar mão para ajudá-lo a preservar a própria vida contra os inimigos, todos tem direito a tudo, inclusive ao corpo alheio" (HOBBES. 2009, p. 98).

Quando Francis Galton cunhou, em 1883, sua tese intitulada de eugenia, é possível que ele tenha imaginado as suas finalidades sociais baseadas no contexto ético bem como no agrupamento de normas morais da época, considerando, para tanto, principalmente o continente europeu. Por outro lado, a Engenharia Genética se desenvolveu a partir dos anos 70, como inovação científica, apesar de já estarem inseridos os controversos em seus conceitos (como a própria eugenia), com o objetivo de melhorar a condição de vida humana diante das fragilidades que o corpo tem frente às intempéries e às degenerações, podendo recuperar, assim, o bem-estar de uma coletividade. Tendo sido esse o propósito, a eugenia seguiu ou está no mesmo caminho de outras grandes revelações que da ingenuidade científica logo se transformaram em bólide sem controle. 
À medida que avançamos na ciência, o culto que se presta à pessoa humana na sua vida latente vai se esvaziando para dar lugar, de início, aos desejos de cura que, posteriormente, mesclam-se com os caprichos do aperfeiçoamento de um fenótipo vencedor. O embrião pesquisável ou não, pode ser submetido à cura ou ao aperfeiçoamento genético, e tem a sua manipulação orientada por diagnósticos, como, por exemplo, o DGPI (diagnóstico genético pré-implantação). Quando se trata de fins terapêuticos, a auto compreensão do processo ético está atrelada à auto compreensão da existência, tendo estas o condão de fazer superar as normas regulamentadoras. O que se busca, aqui, é a intervenção genética como forma de cura de patogenias indubitáveis e irreversíveis. Afirma-se, assim, a eugenia negativa como conduta ética correta.

Quanto à intervenção para melhoramentos genéticos, a princípio, as suas demandas e propósitos estão claros. Mas uma questão vem se especulando quando se tenta estabelecer um estudo ético que contemple as normas morais da manipulação eugênica: existem situações que o conceito de cura se aproxima, em casos concretos, do de aperfeiçoamento, causando um limiar tênue entre eles (ver figura 2), que é agravado pela falta de critérios mais rígidos para defini-los e regulamenta-los. Segundo Habermas "Com o diagnóstico genético de pré-implantação, hoje já é difícil respeitar a fronteira entre a seleção de fatores hereditários indesejáveis[9] e a otimização de fatores desejáveis" (HABERMAS, 2004, p. 29)[10].

Figura 2 - A interface entre eugenias.

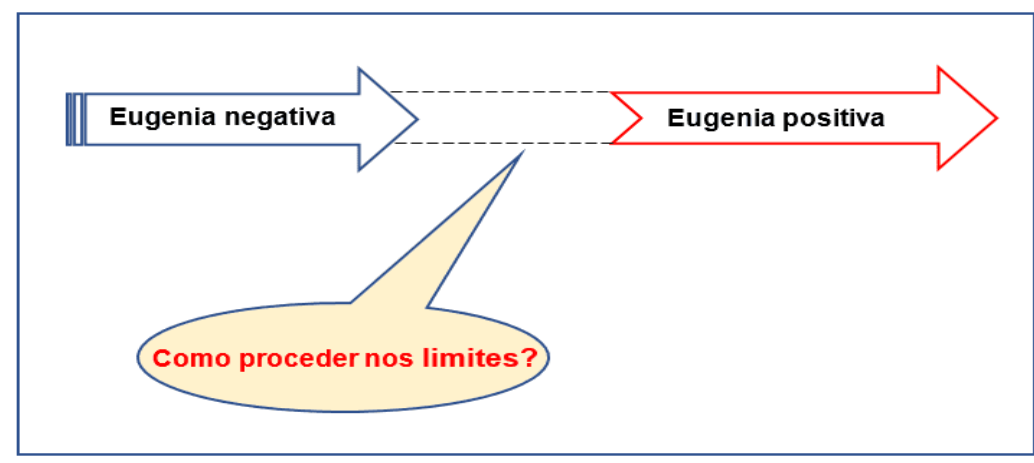

Fonte: Autor (2020) 
Isso tem dado margem para que se instaure uma possibilidade de intervenção em qualquer situação, legitimada pela dúvida normativa. Surge, daí, o que Habermas denomina de eugenia liberal, catalisada por interesses escusos aos princípios morais e à ética. Tomando como base a racionalidade desenvolvida a partir da ação comunicativa (contrapõe a razão instrumental)[11], Habermas expõe o conceito de Kant do imperativo categórico que, por meio de uma de suas derivações, coloca a pessoa como um fim em si mesma e não como meio, como princípio moral no trato com outras pessoas. A isso se refere a formulação-meta do imperativo categórico, em que Kant invoca o valor absoluto da existência humana: "age de tal modo que possas usar a humanidade, tanto em tua pessoa como na pessoa de qualquer outro, sempre como um fim ao mesmo tempo e nunca somente como um meio" (KANT, 1993, p. 79).

Aqui, o imperativo categórico faz uma interface entre a razão instrumental e a razão do agir comunicativo, sobretudo quando coloca o sujeito na formulação da moral, ampliando para o "nós" universal a partir das argumentações das proposições morais no discurso ético. A formulação desse imperativo deve fazer parte da solução de conflitos cujas orientações axiológicas não se conciliam, quando, a partir do Discurso, os sujeitos devem buscar a norma que pode ser aplicada, concretamente, a ele e a todos. O dizer "não" deve ser componente do discurso racional, importante para se criar, sob consenso, a norma universal que se aplica a todos os concernidos. A condição de poder dizer não, ou sim, faz parte da estrutura do poder-ser-si-mesmo que é o que leva à compreensão do ser si mesmo no mundo. Sim e não estão no discurso e no agir, além de fazerem parte do estádio ético do indivíduo que se manifesta em pretensões.

A programação genética é uma ameaça ao poder ser si mesmo porque a existência tem o corpo como tributo, ou seja, somente quando o sujeito cognoscente se sente no corpo é que ele tem a compreensão de ser si mesmo. Esse sentir-se corpo na existência só vem pelo desenvolvimento natural e não pela imposição tecnicizada. Em Hannah Arendt, Habermas extrai de sua tese que o nascimento não é uma continuidade da história de vida (não é um processo histórico, um fazer de novo) e 
sim algo que se fez novo e esse fazer novo só vem pelo nascimento natural, conforme se expressa a filosofa:

O novo começo inerente a cada nascimento pode fazer-se sentir no mundo somente porque o recém-chegado possui a capacidade de iniciar algo novo, isto é, de agir. Neste sentido de iniciativa, todas as atividades humanas possuem um elemento de ação e, portanto, de natalidade (ARENDT, 2007, p. 17).

Ao indivíduo geneticamente modificado não se permite uma renovação de auto compreensão de sua formação gênica, por conta da moral pré-estabelecida de modo alienado, tornando-o, figuradamente, uma terceira pessoa que não consegue, a partir de sua liberdade ética, incluir-se naturalmente no seu processo de socialização e ser o si mesmo de suas aptidões e deficiências. Conforme Habermas, é alguém "assemelhado a um clone" (HABERMAS, 2004, p. 87). O programador da intervenção genética impõe um caráter modificado que vai determinar, irreversivelmente, a compreensão da pessoa que teve seu livro de vida alterado, sem chance de revisão, por conta de uma decisão racional unilateral. A questão não se reduz a simples prescrição normativa moral ou jurídica que vise proteção à pré-pessoa ou à "pessoa aí" no mundo da vida.

Passa, antes, por uma avaliação da forma de lidar com o humano, de compreendêlos dentro da nossa auto compreensão ética. Passa, também, pela inclusão pretérita, com base nos preceitos morais do agir comunicativo, da futura pessoa, no consenso e decisão sobre "o que devo fazer com minha vida", porque:

precisamos nos perguntar se eventualmente as gerações futuras vão se conformar com o fato de não mais se conceberem como autores únicos de suas vidas - e de não serem mais responsabilizadas como tal (HABERMAS, 2004, p. 93).

No que se refere a uma ponderação coletiva da moral podemos, por exemplo. estar inclinados a absorver práticas eugênicas liberais, como aquelas consideradas como 
moralmente aceitas, até mesmo pondo a intervenção terapêutica em segundo plano. Esta possibilidade de um futuro eugênico totalmente relativista tem de ser moderado e mediado pela ética do discurso, ou seja, pelo agir comunicativo, que ainda se recusa a aceitar a auto inclusão do ser humano na sua dominação da natureza a partir dos processos de auto instrumentalização. Saber discernir o certo do errado é uma característica racional fenotípica do "homo sapiens" e é essa virtude que faz, ainda, um enfrentamento à auto instrumentalização da espécie humana e à incerteza do poder ser si mesmo num mundo em que esse si mesmo precisa decorrer de uma auto compreensão ética.

Aí está a base para a inclusão da segunda pessoa no processo de socialização, tendo como matriz de construção ética, os valores morais de "estatuto perpétuo" da natureza e $o$ agir comunicativo que se processa quando o ser subjetivo se lança no mundo a partir da intersubjetividade e, também, da alteridade. O modelo adequado para integrar a filosofia na interdisciplinaridade do tema bioético de manipulação genética da espécie, teve na linha de pensamento de Habermas o necessário fundamento para se fazer uma revisão dos alicerces da filosofia tradicional. Tenta alcançar, para isso, um entendimento da moral e da ética na dominação do devir natural, causada pela antropização, o que acarreta alterações dos cenários ontológicos e antropológicos, cujo próprio ser humano é, portanto, protagonista, tanto ativo como passivo.

As alterações efetuadas nos genomas são atitudes que não encontram recepção na moral universalizada pela ética do discurso e nem na liberdade de poder ser si mesmo do indivíduo, principalmente quando visa, exclusivamente, melhoramentos genéticos porque transgrede a autonomia e a igualdade de pessoas [12]. Por isso ele defende a manipulação genética apenas para fins terapêuticos e eleva sua crítica à eugenia positiva:

O corpo repleto de próteses, destinadas a aumentar o rendimento, ou a inteligência dos anjos, gravada no disco rígido, são imagens fantásticas. Estas apagam as linhas fronteiriças e desfazem as coerências que até o momento se apresentaram a nosso agir quotidiano como transcendentalmente necessárias. De um lado, o ser orgânico que 
cresceu naturalmente se funde com o ser produzido de forma técnica; de outro, a produtividade do intelecto humano separa-se da subjetividade vivenciada (HABERMAS, 2004, p. 58).

É por meio dessa subjetividade vivenciada que a pessoa dialoga e acessa a intersubjetividade e alteridade no mundo ético da vida. $E$, superando a questão do "que fazer com o tempo da minha vida" (HABERMAS, 2004, p. 3), ela se articula a partir de uma reflexiva auto compreensão ética para dar um salto para outra questão de maior conteúdo moral, a saber: "O que eu devo fazer, o que nós devemos fazer?" (HABERMAS, ibidem, p. 5). Ela busca a resposta agora com o "eu" e o "nós" inclusivos, cuja identidade do "eu" está associada ao que eu desejo para o outro, mantendo-se íntegra a dignidade e a liberdade de cada um no seu processo de construção histórica da vida. Nesse contexto, insere-se as questões da manipulação genética que, como uma boa providência científica, convergiu para um dos temas mais polêmicos da atualidade - a eugenia.

A questão do sujeito no mundo da vida, diante das intervenções genéticas, passa a ser tratada por Habermas como uma necessidade de reconhecimento da auto compreensão da existência, cujo indivíduo, de posse de uma auto compreensão ética, passa a ser o sujeito da intersubjetividade, elaborando e argumentando proposições morais para intervir no discurso ético. A eugenia liberal, como um provável capítulo da história, tem que ser tratada como algo desconstrutivo da dignidade humana que, associada à perda da autenticidade do indivíduo com a alteração da sua identidade genética, via alteração cromossômica, impõe novos desafios à ética filosófica.

Nesse ponto, Habermas desloca o pensar para a razão da linguagem, deixando de lado os modelos éticos tradicionais baseados no idealismo, na abstração, e passa a formular um modelo ético, ou pelo menos suas bases, despertando para a ciência, a política e a sociedade pós-moderna a necessidade de reflexão sobre o futuro de uma humanidade fragilizada e potencialmente instrumentalizada. De certa forma, mesmo que de modo ainda cauteloso diante de um tema tão recente, é preciso ter cuidado ao elaborar argumentos morais decisivos. Assim, Habermas propõe, como já salientamos, a tratar o assunto contemplando o sujeito, de maneira pretérita, dentro 
do discurso ético[13]. É na linguagem do agir comunicativo, mesmo extemporâneo, que são construídos os valores morais para serem implementados no agir ético, busca-se, precisamente, a auto compreensão ética antes de elaborar normas do dever ser, morais ou jurídicas, introduzidas, difundidas e internalizadas nas decisões políticas.

Tal consciência ética, segundo Habermas, deve impregnar a mente daqueles que por heterodeterminação decidem apostar em um fenótipo "melhorado", modificando eugenicamente o genoma humano, isto é, por imposição de uma vontade alheia à uma segunda pessoa que deveria ser participante de uma deliberação intersubjetiva. Baseado nisto e de acordo com o pensamento habermasiano sobre o tema, a decisão sobre a eugenia tem que ser ponderada (ver figura 3). Nesse caso, a eugenia negativa pode ser aceita moralmente e legalmente, pois, aí pode-se tentar integrar o indivíduo em uma dignidade que está sob ameaça. Essa ponderação alcança as definições dos limites, as vezes tênue, entre a eugenia negativa e a positiva, ou seja, entre a terapia genética e a busca da perfeição.

Figura 3 - Matriz de valores para ponderação dos procedimentos de técnicas genéticas.

\begin{tabular}{|c|c|c|}
\hline Técnica & Efeitos atribuídos à técnica & Valor \\
\hline DGPI & $\begin{array}{l}\text { Informações cromossômicas para implante do } \\
\text { embrião } \\
\text {. Descarte de embriões não saudáveis }\end{array}$ & + \\
\hline Pesquisa & $\begin{array}{l}\text { Descarte de qualquer tipo de embrião } \\
\text { Novas descobertas para a medicina }\end{array}$ & - \\
\hline Intervenção & $\begin{array}{l}\text { Cura que, moralmente justificada, proporciona à } \\
\text { segunda pessoa inclusão no processo de socialização }\end{array}$ & + \\
\hline
\end{tabular}




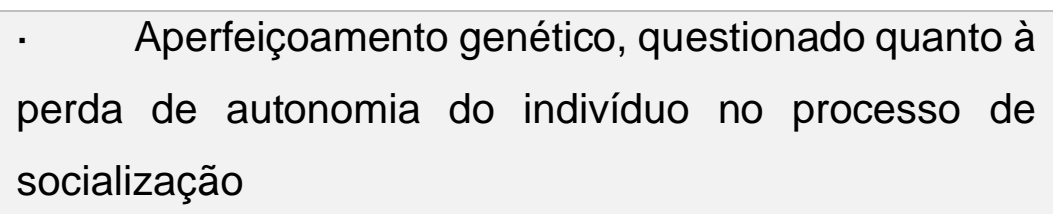

Fonte: Autor (2020)

\section{CONSIDERAÇÕES FINAIS}

Habermas não traz uma prescrição última, definitiva, para solucionar a problemática apresentada neste estudo. Contudo, ele faz um delineamento no qual apresenta os mecanismos morais que podem ser aplicados nas decisões que envolvem a autoafirmação da existência da vida humana. A grande preocupação dele é com o rumo que a manipulação eugênica pode tomar se esses mecanismos interferentes no agir das pessoas não forem levados em consideração. Por isso ele aposta na razão comunicativa, na intersubjetividade, na validação de argumentos morais sob consenso e na auto compreensão ética para tentar evitar um esmaecimento de identidade e autonomia do indivíduo no futuro da natureza humana. A figura 4 mostra, em síntese, a proposta de Habermas. 
Figura 4 - Síntese de uma proposta para a ética da eugenia.

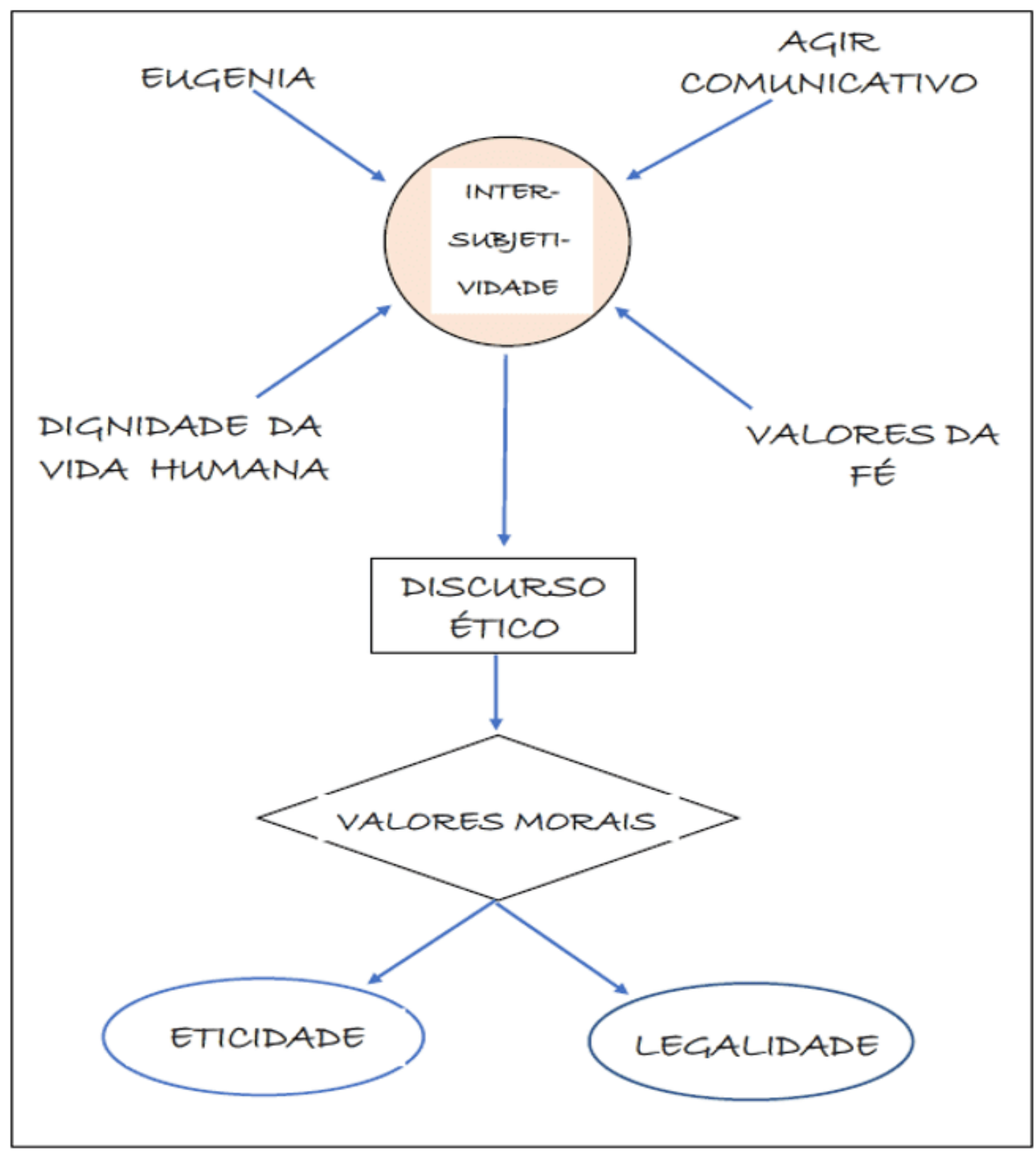

Fonte: Autor (2020)

Uma vez que a comunicação racional, por meio da linguagem filosófica, passa a ser o instrumento da ética prática, ela pode ser ampliada, também, para outros horizontes relacionais do ser humano, como, por exemplo, a política e a família. Deixa-se à parte as ideias platônicas e os modelos hegelianos de formatação da ética porque, como vimos, ela pode ser encontrada na realidade do mundo da vida, ao se dar primazia à 
práxis no lugar da teoria. A ciência, a teologia e a metafísica, ao nosso ver, não devem ser negados como meios de conhecimento, mas a ética tem que estar ancorada numa razão que permeia a conexão entre pensamentos de sujeitos, manifestada pelo agir e pela linguagem, e, portanto, há sujeitos com capacidade de fala e de ação sempre, o que faz com que seja possível atingir consenso sobre os valores morais pertinentes ao agir ético de uma coletividade.

Finalmente consideramos que o si mesmo não deve ser apenas uma possibilidade, mas sim um direito natural, no seu sentido lato, e, dessa forma, um indivíduo o adquire mesmo na pré-pessoa, e, portanto, o embrião humano, mesmo na fase de blastócito, pode não ser pessoa ainda na sua completude, conforme aduz Habermas, mas é sujeito com todos os direitos de ser pessoa. Razão assiste ao autor quando se refere à dignidade da vida humana desde a sua concepção. Cremos, também, que essa é a fundamentação necessária para objetar os interesses escusos da ciência, da política e do mercado, que, hoje, embarreiram o estabelecimento de normas legais com lastros autenticamente morais. Pode até parecer estranho ou atípico para a nossa sociedade configurar condutas e mudanças culturais a partir de um entendimento movido pela auto compreensão, mas, a Filosofia, não pode se esquivar desta missão

\section{REFERÊNCIAS}

ARENDT, H. A condição humana. Trad. Roberto Raposo. Rio de Janeiro: Forense Universitária, 2007.

GALTON, Francis. Hereditary Talent and Genius. Apud: GOLDIM, José Roberto, 1998. Eugenia. Disponível em: www.ufrgs.br/bioetica/eugenia.htm. Acesso em: 05 jun. 2018.

HABERMAS, J. Consciência moral e agir comunicativo. Trad. de Guido Antônio de Almeida. Rio de Janeiro: Edições Tempo Brasileiro, 1989.

HABERMAS, J. 0 futuro da Natureza Humana. Trad. Karina Janini. São Paulo: Martins Fontes, 2004. 
HABERMAS, J. Pensamento Pós-metafísico - Estudos Filosóficoa. Trad. de Flávio Siebeneichler. Rio de Janeiro: Edições Tempo Brasileiro, 1990.

HOBBES, T. Leviatã - ou a matéria, forma e poder de um Estado eclesiástico e civil. Trad. Rosina D`Angina. São Paulo: Martin Claret, 2009.

KANT, I. Fundamentos da Metafísica dos Costumes. Trad. Lourival de Queiroz Henkel. Rio de Janeiro: Tecnoprint, 1993.

KIERKEGAARD, S. Ou - Ou: Um fragmento de vida. Lisboa: Relógio D'água, 2013.

NUNES, B. A Filosofia Contemporânea. São Paulo: Editora Buriti, 1967.

PINZANI, A. Habermas. Porto Alegre: Artmed, 2008.

RAWLS, J. Uma teoria da Justiça. Trad. Almiro Piseta. São Paulo: Martins Fontes, 2000.

ROUSSEAU, J. J. Do Contrato Social. Trad. Pietro Nassetti. São Paulo: Martin Claret, 2000.

\section{APÊNDICE - REFERÊNCIAS DE NOTA DE RODAPÉ}

3. Fenótipo: característica aparente ou observável de um indivíduo, determinada pela interação genética e condições ambientais.

4.htttp://www.genome.gov/Pages/Hyperion//DIR/VIP/Glossary/llustration/Pdf/insertio n.pdf. Acesso em 03/09/2018. Domínio Público (Acess in september/03/2018. Public Domain).

5. Significa dizer que a pós-metafísica chega ao limite de seu epokhé (suspensão de juízo) no tratamento de assuntos ligadas à vida correta ou a vida fracassada, quando entra em jogo a autocompreensão ética de "sujeitos capacitados para a linguagem e para a ação", ou seja, é o momento em que ela não pode mais ficar contida somente nos espaços que ela vinha até agora atuando. 
6. Em síntese, o pensamento de Habermas se destaca pela crítica ao positivismo e reformulação da teoria marxista, além de criticar também o que se denominou de "razão instrumental", afirmando que é pelo emprego da linguagem e a ação que as pessoas adquirem e usam o conhecimento e expressam seus desejos e objetivos. A ação comunicativa se dá quando os sujeitos da ação acordam, em livre vontade, sobre seus alvos e dá o tom da racionalidade empregada para alcançá-los. Destaca-se aí, então, o critério da intersubjetividade, a interação entre sujeitos (seres humanos) como alternativa para a "razão instrumental" definida como a "faculdade que julga, discerne, compara, relaciona, ordena e coordena os meios com os fins". É através desse agir comunicativo que o indivíduo consegue criar seus próprios espaços, livre das amarras do mundo da consciência.

7. Refere-se às diferentes esferas da vida, e não tem o significado de estados de evolução; daí ser chamado de estádios.

8. Segundo o Dicionário Informal da Língua Portuguesa é a forma como a pessoa percebe e interpreta a si mesma, o que nem sempre corresponde à realidade.

9. Motivo da intervenção genética terapêutica

10. Motivo da intervenção genética de aperfeiçoamento

11. A razão instrumental é voltada para o domínio (controle) da natureza, e do próprio homem. O sujeito interpreta o mundo à sua maneira.

12. Habermas traz de Kant a autonomia como o princípio maior da moralidade

13. Trata-se de uma antevisão da decisão do indivíduo, com base nas consequências que uma intervenção tem em uma socialização projetada da futura pessoa humana que tem capacidade para falar e agir.

Enviado: Outubro, 2019.

Aprovado: Janeiro, 2020. 